\title{
PEMBINAAN KESADARAN BELAJAR MATEMATIKA MELALUI PENDEKATAN HISTORIS PADA SISWA SMA NEGERI 6 PADANGSIDIMPUAN
}

\author{
Marzuki Ahmad $^{1)}$; Dwi Putria Nasution ${ }^{2)}$ \\ ${ }^{1)}$ Fakultas Pendidikan MIPA, Institut Pendidikan Tapanuli Selatan \\ ${ }^{2}$ SMA Negeri 2 Padangsidimpuan \\ e-mail: Marzuki.ahmad45@yahoo.com
}

\begin{abstract}
The specific purpose of this service activity is to build awareness of learning mathematics through a historical approach to SMA Negeri 6 Padangsidimpuan students so that they are able to apply it in daily life. The method of implementing activities adopts patterns of planning, implementation, observation and evaluation, reflection. To be able to increase awareness of learning mathematics students are taught mathematics with a historical approach.Awareness of mathematics learning in class X MIA 2 SMA Negeri 6 Padangsidimpuan students with the number of students as many as 32 people in terms of aspects of behavior, habits, learning styles and learning personality of students through a historical approach can increase. This increase can be seen from the average value of the initial results of the student learning awareness questionnaire (73.79) in the medium category and the final average score of the student awareness questionnaire (79.41) is in the good category. Service activities in mathematics learning with a historical approach benefit students because students better understand the mathematics material being studied, students feel very interested and students are more happy in mathematics learning activities.
\end{abstract}

Keywords: Learning Awareness, Mathematical Learning, Historical Approach

\begin{abstract}
Abstrak
Tujuan khusus kegiatan pengabdian ini adalah untuk membangun kesadaran belajar matematika melalui pendekatan historis pada siswa SMA Negeri 6 Padangsidimpuan sehingga mampu mengaplikasikan dalam kehidupan sehari-hari. Metode pelaksanaan kegiatan menggadopsi pola kegiatan perencanaan, pelaksanaan, observasi dan evaluasi, refleksi. Untuk dapat meningkatkan kesadaran belajar matematika siswa dilakukan pembelajaran matematika dengan pendekatan historis. Kesadaran belajar matematika siswa kelas X MIA 2 SMA Negeri 6 Padangsidimpuan dengan jumlah siswa sebanyak 32 orang ditinjau dari aspek prilaku, kebiasaan, gaya belajar dan kepribadian belajar siswa melalui pendekatan historis dapat meningkat. Peningkatan ini dapat dilihat dari nilai rata rata hasil awal angket kesadaran belajar siswa $(73,79)$ berada dalam kategori sedang dan nilai rata rata akhir angket kesadaran siswa $(79,41)$ berada dalam kategori baik. Kegiatan pengabdian dalam pembelajaran matematika dengan pendekatan historis memberi manfaat bagi siswa karena siswa lebih memahami materi matematika yang dipelajari, siswa merasa sangat berminat dan siswa lebih senang dalam kegiatan pembelajaran matematika.
\end{abstract}

Kata Kunci: Kesadaran Belajar, Pembelajaran Matematika, Pendekatan Historis

MARTABE : Jurnal Pengabdian Masyarakat| 45 


\section{PENDAHULUAN}

Kesadaran merupakan kekuatan mendasar yang sangat penting dan terdapat pada pikiran. Kekuatan tersebut jika dioptimalisasikan akan dapat digunakan untuk menghasilkan sesuatu. Kesadaran belajar merupakan hal yang sangat penting ditumbuhkan siswa sebagai perserta didik. Dengan adanya kesadaran belajar yang baik pada siswa sebagai subjek belajar, siswa akan aktif dalam kegiatan pembelajaran baik secara mandiri atau bersama-sama yang dapat memberi dampak pada hasil yang diperoleh akan mamuaskan. Selanjutnya Istiyani (2009) mengungkapkan hal yang paling penting dalam kegiatan pembelajaran adalah kegiatan belajar mengajar dilakukan dengan kemauan dan kesadaran dari dalam diri sendiri sehingga peserta didik akan lebih mempunyai semangat yang luar biasa dalam belajar. Selanjutnya kesadaran diri merupakan alternatif untuk memaksimalkan kegiatan pembelajaran pada peserta didik, karena kesadaran merupakan modal penting bagi peserta didik dalam memperoleh pengetahuan dan pendidikan (Nurulia, 2016). Dengan demikian kesadaran belajar merupakan suatu kekuatan yang terdapat pada pikiran untuk menambahkan pemahaman atau pengalaman jika dioptimalisasikan akan dapat menghasilkan pengetahuan baru.

Berdasarkan hasil wawancara dengan salah satu guru SMA Negeri Padangsidimpuan, diperoleh informasi secara umum bahwa, pembelajaran matematika yang dilaksanakan SMA Negeri Padangsidimpuan selama ini adalah dalam 4 (Empat) tahun ini telah mencoba mengikuti K-13. Berbagai upaya telah dilakukan oleh guru dalam pembelajaran baik terkait dengan metode, model dan materi pembelajaran, namun kegiatan pembelajaran yang terjadi secara umum belum berjalan dengan baik dimana siswa cendrung pasif dan pembelajaran kurang menarik bagi siswa. Untuk dapat meningkatkan aktivitas siswa dalam pembelajaran perlu memperhatikan kesadaran belajar siswa. Jika kesadaran belajar siswa baik maka siswa akan dapat belajar secara mandiri, belajar dengan teman sebanya da belajar dari orang dewasa (guru).

Sebagai mitra dalam pelaksanaan kegiatan Pengabdian kepada Masyarakat (PkM) ini adalah SMA Negeri 6 Padangsidimpuan. Berdasarkan analisis situasi dapat teridentifikasi beberapa permasalahan yang dihadapai oleh mitra, antara lain siswa kurang berminat dalam megikuti kegiatan pembelajaran matematika, motivasi siswa dalam kegiatan pembelajaran matematika kurang, pemahaman siswa terhadap materi yang dipelajari kurang, siswa cepat merasa bosan dalam kegiatan belajar matematika dan pemahaman siswa dalam pembelajaran matematika tidak mendalam, kegiatan penyampaian materi pelajaran matematika kurang melibatkan aspek sejarah lahirnya konsep-konsep matematika yang ada. Harahap, dkk. (2017) mengungkapkan bahwa kebosanan siswa dalam kegiatan pembelajaran dan rendahnya pemahaman siswa pada konsep dasar adalah dampak dari pembelajaran konvensional.

Mencermati dari rendahnya aktivitas aktif siswa dan motivasi belajar siwa kami memandang perlu meningkatkan kesadaran belajar bagi siswa. Kesadaran belajar siswa sangat dibutuhkan dalam kegiatan belajar mengajar agar siswa mempunyai kemauan sendiri untuk belajar, mempunyai kesadaran untuk belajar sendiri walaupun guru tidak ada di dalam kelas (Sukoyo, 2014). Tugas guru yang paling utama adalah membentuk kesadaran belajar siswa karena dengan adanya kesadaran belajar, proses belajar mengajar di dalam kelas akan berjalan dengan mudah, sesuai dengan apa yang ingin dicapai oleh seorang guru (Fahmi, 2015).

Proses belajar mengajar di lingkungan sekolah sebaiknya diterapkan dengan memperhatikan minat siswa sehingga siswa lebih berminat dalam 
pembelajaran dan lebih memahami materi pelajaran. Sekolah salah satu lembaga pendidikan yang memberi kebebasan untuk menentukan metode, teknis, dan strategi belajar mengajar sesesuai dengan karakteristik anak didik, guru, dan sarana belajar (Ilyas, 2016). Selanjunya Ahmad \& Nasution (2018) mengungkapkan bahwa untuk mencapai hasil yang baik dalam kegiatan pembelajaran, seorang guru hendaknya dapat menciptakan lingkungan belajar yang menyenangkan dan memungkinkan bagi siswa untuk aktif belajar dengan mengkonstruksi dan mengembangkan pengetahuannya. Melalui aktifnya siswa dalam pembelajaran maka siswa akan mengeksplorasi materi pembelajaran hingga mampu memahami matematika secara mendalam. Pemberian pengalaman secara langsung pada siswa dalam pembelajaran sangat penting, untuk mengembangkan kompetensi, sehingga siswa dapat bereksplorasi dan memahami alam sekitar secara ilmiah dengan mendalam (Lubis, dkk., 2018).

Siswa perlu belajar matematika secara aktif dengan membahas berbagai peristiwa dengan memperhatikan unsur tempat, waktu, obyek, latar belakang, dan pelaku dari penemu ilmu-ilmu matematika. Proses pembelajaran merupakan aktivitas yang terdiri atas komponen-komponen yang bersifat sistemik (Abusiri, 2017). Komponen-komponen yang digunakan dalam pembelajaran saling berkaitan dan saling mendukung untuk kelancaran proses dan mendukung tercapainya tujuan pembelajaran. Pembahasan materi pelajaran diawali dengan melakukan pengkajian sejarah lahirnya ilmuan dan konsep materi pelajaran yang dilanjutkan dengan pembahasan materi pelajaran. Pendekatan historis merupakan pendekatan pembelajaran yang menjadikan sejarah dari bidang yang dipelajari sebagai sumber atau acuan dasar dalam penyampaian materi pelajaran. Berkaitan dengan hal tersebut kami memandang perlu untuk mengadakan kegiatan Pengabdian kepada Masyarakat (PkM) yang melibatkan pembinaan kesadaran belajar matematika dengan pendekatan historis pada siswasiswi SMA Negeri 6 Padangsidimpuan tahun ajaran 2018/2019.

\section{METODE}

Proses perancangan kegiatan program pembinaan kesadaran belajar matematika melalui pendekatan historis pada siswa SMA Negeri 6 Padangsidimpuan dilaksanakan secara inovatif. Prosesnya disesuaikan dengan kondisi lapangan, dengan terlebih dahulu melakukan analisis kebutuhan terkait dengan analisis siswa, materi dan spesifikasi tujuan pelajaran matematika yang esensial. Selanjutnya dilakukan analisis kebutuhan yang diperlukan untuk produksi perangkat pembelajaran untuk pelaksanaan kegiatan pengabdian. Tahapan proses kegitan dapat diamati pada gambar 1 berikut.

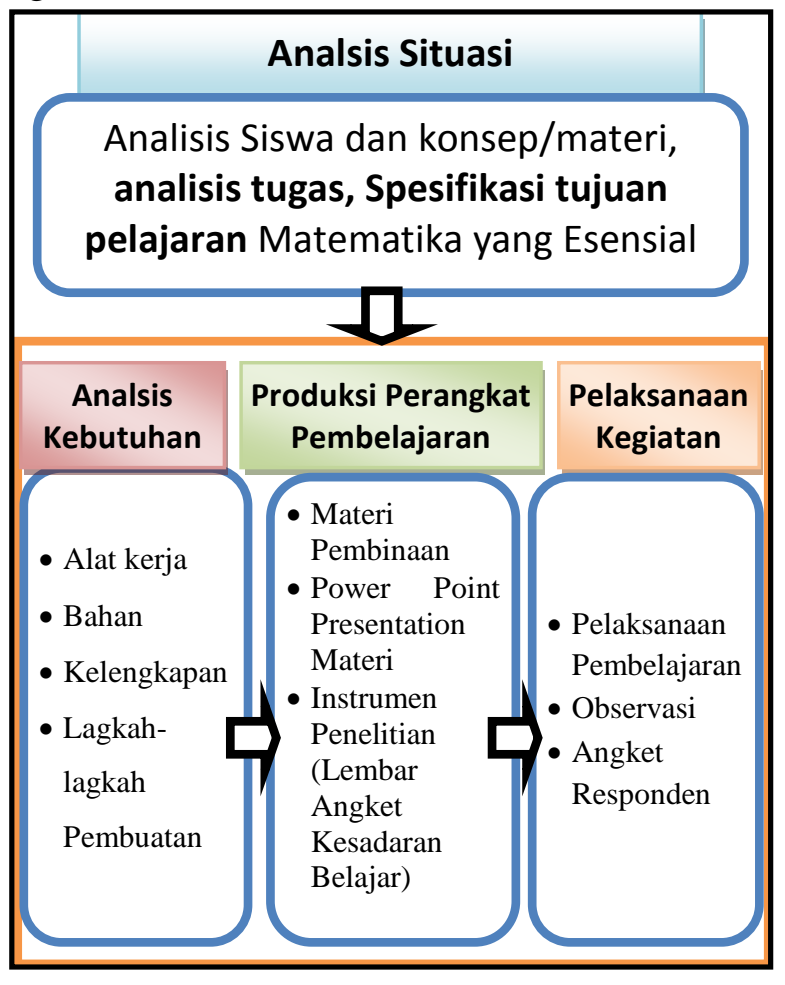

\section{Gambar. 1. Prosedur Kegiatan}

Rancangan mekanisme pelaksanaan kegiatan PkM ini dilakukan dengan mengadopsi langkah-langkah action research yang terdiri dari 4 (empat) tahapan, yaitu: perencanaan, tindakan, observasi dan evaluasi, dan refleksi. Bagan 
ke-Empat tahapan tersebut digambarkan sebagai berikut.

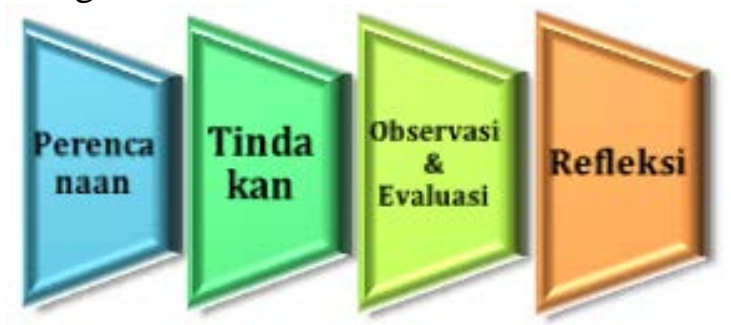

Gambar 2. Tahapan Kegiatan Inti

Kegiatan-kegiatan dari masingmasing tahapan adalah sebagai berikut.

\section{a. Perencanaan}

Kegiatan-kegiatan yang dilakukan pada tahap perencanaan adalah menyusun perangkat yang diperlukan dalam kegiatan, menentukan narasumber yang akan menerapkan pembelajaran matematika melalui pendekatan historis, menetapkan hari pelaksanaan dengan menyesuaikan jadwal yang dimiliki oleh tim dan sekolah tempat pelaksana kegiatan, dan melengkapi seluruh hal-hal yang diperlukan dalam pelaksanaan kegiatan.

b. Tindakan

Tindakan dalam kegiatan ini berupa implementasi Program. Kegiatan-kegiatan yang dilakukan dalam implementasi program adalah

1. Pemberian angket awal kesadaran belajar matematika siswa.

2. Mewawancara siswa untuk mendapatkan data pembanding dari hasil angket kesadaran belajar siswa dan sekaligus untuk memperdalam tentang situasi kesadaran belajar matematika siswa.

3. Memberikan pemahaman materi sejarah siswa secara umum yang dikaitkan dengan sejarah ilmuan matematika, memberikan pemahaman mendalam tentang penemuan para ahli matematika yang di terapkan dalam pembelajaran SMA dan kontribusinya terhadap Ilmu Pengetahuan dan Teknologi (IPTEK).

4. Pemberian angket akhir kesadaran belajar matematika siswa stelah transfer pemahaman materi sejarah dan pemahaman mendalam terhadap temuan para ahli dibidang matematika dan kontribusinya dalam IPTEK yang disertai dengan pertanyaan pendukung.

c. Observasi dan Evaluasi

Observasi dilakukan terhadap proses pelaksanaan program yang bejalan dilingkungan mitra. Observasi dilakukan oleh satu orang yang bertugas memantau jalannya kegiatan program. Selahjutnya analisis hasil evaluasi dilakukan pada tahapan awal dan khir kegiatan berupa pemberian angket respon sebagai mana yang telah terlaksana pada tahap tindakan. Program dianggap berhasil jika respon siswa terhadap kesadaran belajar matematika meningkat.

d. Refleksi

Refleksi dilakukan terhadap kegiatan yang telah dilaksanakan. Hal ini dilakukan untuk mengetahui kekurangankekurangan atau kelebihan-kelebihan terhadap kegiatan-kegiatan yang telah dilakukan dalam rangka untuk menetapkan rekomendasi terhadap keberlangsungan atau pengembangan kegiatan-kegiatan berikutnya. Melalui tahapan refleksi diperoleh kesimpulan akhir dari siklus kegiatan yang dilaksanakan.

\section{HASIL DAN PEMBAHASAN \\ Perencanaan}

Perencanaan kegiatan dilakukan berdasarkan analisis situasi tentang karakteristik dan kondisi siswa SMA khususnya siswa SMA Negeri 6 padangsidimpuan. Analisis situasi dilakukan melalui studi kepustakaan dan pengamatan terhadap kegiatan pembelajaran siswa, khususnya kelas $\mathrm{X}$ MIA 2 SMA Negeri 6 Padangsidimpuan. Pengamatan dan studi kepustakaan dilakukan terhadap prilaku, kebiasaan, gaya dan kepribadian yang dimiliki siswa dalam pelaksanaan kegiatan pembelajaran. Tujuan dari analisis situasi yang dilakukan adalah untuk mendapatkan gambaran mendalam tentang realitas situasi siswa dalam pembelajaran. Berdasarkan data 
tersebut disusun perangkat pembelajaran dengan pendekatan historis dan instrumen angket yang bertujuan untuk mengukur kesadaran belajar matematika siswa.

Perangkat pembelajaran meliputi bahan yang akan diajrkan kepada siswa. bahan ajar yang akan disampaikan disesuaikan dengan tingkat pelajaran siswa SMA kelas $\mathrm{X}$ (Sepuluh) yang disusun melalui pendekatan aspek sejarah temuan lahirnya teori-teori matematika. Bahan ajar memiliki peran penting dalam pembelajaran, bahan ajar perlu dirancang khusus agar sesuai dengan materi, prinsip pedagogi, dan menarik bagi siswa (Fitriani, dkk., 2018). Angket kesadaraan matematika siswa disusun sebanyak 20 item. Butir pertanyaan angket yang digunakan mengacu pada indikator yang digunakan yaitu 5 soal dengan indikator prilaku belajar siswa, 5 soal dari indikator kebiasaan belajar siswa, 5 soal dari indikator gaya belajar siswa, dan soal dari indikator kepribadian belajar siswa. Butir-butir pernyataan siswa dibuat dalam bentuk pernyataan positif sebanyak 10 pernyataan dan bentuk pernyataan negatif sebanyak 10 pernyataan. Adapun kisi-kisi dari angket kesadaran belajar matematika siswa dapat diamati pada tabel berikut.

Tabel. 1. Kisi-kisi angket kesadaran belajar

\begin{tabular}{|lcc|}
\hline \multirow{2}{*}{\multicolumn{1}{c}{ Indikator }} & \multicolumn{2}{c|}{ Butir Soal } \\
\cline { 2 - 3 } & Positif & Negatif \\
\hline Perilaku dalam belajar & $1,4,20$ & 2,3 \\
\hline Kebiasaan dalam belajar & 5,7 & $8,6,9$ \\
\hline Gaya dalam belajar & $11,12,13$ & 10,14 \\
\hline Kepribadian dalam belajar & 16,17 & $15,18,19$ \\
\hline
\end{tabular}

Angket yang disusun berupa pernyataan dengan mengharapkan tanggapan siswa untuk mengisi tanda ceklis $(\sqrt{ })$ pada kolom pilihan SS : Sangat Setuju, S : Setuju, TS : Tidak Setuju, STS : Sangat Tidak Setuju. Selanjutnya siswa diberi pertanyaan terkait dengan keberminatan siswa mengikuti kegiatan pembelajaran matematika, kemudian menanyakan alternatif solusi dari ketidakberminatan siswa dalam kegiatan pembelajaran matematika, menanyakan tentang bagaimana keterpahaman siswa tentang sejarah matematika, dan menanyakan tokoh matematika yang dikenal atau dipahami siswa dengan menjelaskan keterkaitannya dengan kegiatan pembelajaran matematika yang dilanjutkan dengan wawancara terhadap siswa guna mendapatkan jawaban yang lebih jelas dengan melakukan wawancara terhadap siswa dengan pertimbangan dapat memberikan informasi ssecara jelas.

Sebelum melaksanakan tindakan, siswa sebagai peserta yang menjadi objek kegiatan diberikan angket pre-test dan dilakukan wawancara terhadap beberapa siswa. Berdasarkan hasil angket maka dipilih siswa untuk dikenai wawancara dengan menanyakan terkait pada kesadaran belajar siswa dalam pembelajaran matematika. Wawancara dilakukan dengan menanyakan secara langsung terhadap keberminatan siswa dalam pembelajaran matematika, bagaimana penerapan pembelajaran matematika dalam kelas yang diharapkan siswa, keterpahaman siswa terhadap sejarah-sejarah lahirnya ilmu matematika dan keberminatan siswa dalam mengikuti pembelajaran dengan pendekatan historis.

Wawancara dilakukan terhadap siswa dengan tujuan untuk memperjelas situasi siswa secara mendalam dan sebagai pembanding dari hasil angket yang diperoleh. Melalui wawancara yang dilakukan diperoleh informasi mendalam tentang situasi siswa yang menjadi panduan untuk menerapkan kegiatan.

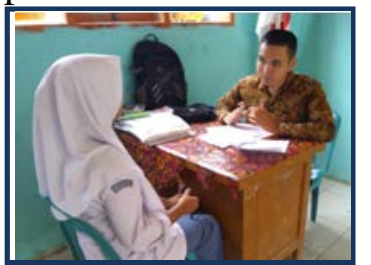

Wawancara responden 1

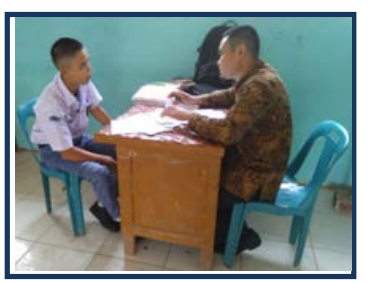

Wawancara responden 3
Wawancara responden 2

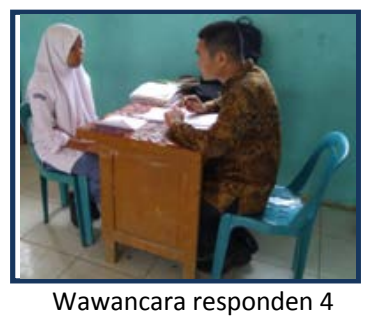

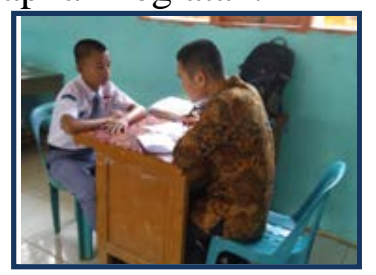

Gambar 3. Wawancara Peneliti dengan responden (siswa) 


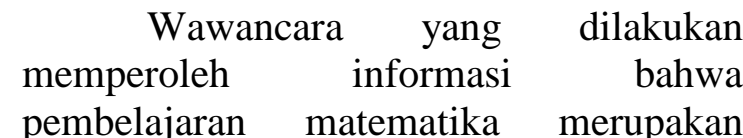
pelajaran yang sulit/rumit, kurang menarik, dalam proses pembelajarannya cendrung membosankan bagi siswa, siswa susah memahami materi pelajaran dan siswa memberi saran agar pembelajaran perlu dijelaskan kembali atau berulang dan perlu mengaitkan tokoh-tokoh matematika untuk meningkatkan motivasi dalam kegiatan pembelajaran karena pengajaran materi pelajaran jarang diungkapkan sejarah-sejarah lahirnya ilmu-ilmu matematika/ dalam pembelajarannya sagat jarang mengaitkan materi yang akan dipelajari dengan tokoh-tokoh penemu dari matematika, siswa tertarik untuk mengikuti pembelajaran matematika dengan pendekatan sejarah.

Melalui analisis tentang tokoh sejarawan dalam matematika ditemukan sangat banyak tokoh yang memberikan sumbangsih dalam perkembangan ilmu matematika. Rama

mengungkapkan 43 tokoh yang berperan dalam penemuan bidang matematika, beberapa tokoh yang dikemukakan antaralain Carl Friedrich Gauss yaitu penemu teori bilangan, Daniel Bernoulli yaitu penemu hukum bernoulli, Evariste Galois yang tokoh matematikawan yang merumuskan dasar teori himpunan, Habash al-Hasib al-Marwazi yaitu penggagas pertama kali rasio trigonometri: Sinus (SIN), Cosinus (COS), Tangen (TAN) dan Cotangen (COT), John Venn yaitu penemu diagram venn, Karl Weierstrass yaitu mengembangkan teori lengkap tentang deret fungsi dan menyusun legitimasi operasi-operasi yang demikian sebagai pengintegralan dan pendiferensialan suku demi suku, Pythagoras dari negara Yunani tahun 582493 SM. yang merupakan bapak bilangan, Thales yaitu penemu teorema thales. Selanjutnya terdapat juga tokoh lain yaitu Abu Al-Qasim Salmah Bin Ahmad AlMajriti, Al-Battani yaitu bapak trigonometri, Al Biruni yaitu ilmuwan yang menguasai beragam ilmu, Al-Farabi tahun 870-950 (Fathurrohman, 2014). Dengan adanya hasil temuan yang diperoleh dari para ahli, dalam kegiatan tahap pelaksanaan diangkat 4 tokoh sejarah yang berperan dalam perkembangan ilmu matematika. Keempat tokoh sejarawan matematika yang dipilih tersebut adalah Pythagoras, Tales, John Venn dan Al-battani.

\section{Tindakan}

Tindakan yang dilakukan dalam pengabdian adalah menerapkan pembelajaran matematika dengan pendekatan historis untuk meningkatkan kesadaran belajar matematika siswa. Keaitan yang dilakukan di awali dengan pemberian angket awal (pretes) tentang kesadaran belajar matematika siswa. Setelah pretes dilakukan dilanjutkan dengan dengan kegiatan pembelajaran matematika dengan pendekatan historis yang dilanjutkan kembali dengan pemberian angket akhir kesadaran belajar matematika (postes). Kegiatan pembelajaran dilakukan dengan menjelaskan beberapa sejarah tokoh matematika dan kontribusi dari tokoh tersebut dalam perkembangan ilmu matematika dan pembahasan teorinya secara mendalam. Sejarawan dari tokoh matematika yang dijelaskan adalah Pythagoras, Thales, John Venn dan AlBattani. Pembahasan tentang sejarah ilmuan matematika dilakukan dengan menjelaskan informasi pribadi, temuan dari tokoh dalam bidang matematika, dan menjelaskan penerapan temuannya dalam bidang matematika. Pelaksanaan tindakan melibatkan narasumber yang dianggap dapat menjelaskan materi sesuai dengan nama tokoh matematika dan temuan tokoh serta penerapan temuan tokoh dalam pembelajaran matematika.

Kegiatan pembelajaran dilakukan sebanyak empat kali pertemuan. Pertemuan petama membahas materi terkait dengan tokoh matemtika Pythagoras, pertemuan kedua membahas 
materi kerkait dengan tokoh Thales, pertemuan ke tiga membahas materi terkait dengan tokoh John Venn, pertemuan keempat membahas materi terkait dengan tokoh Al-Battani. Secara umum kegiatan ceramah yang dilakukan dari keempat penyaji meliputi kegiatan perkenalan, kegiatan menyampaikan informasi pribadi dari tokoh-tokoh matematika, menjelaskan temuannya dalam pendidikan matematika dan mengembangkan temuannya dalam pembelajaran matematika dan melakukan pembahasan mendalam terkait temuan sejarawan matematika.

Kegiatan pembelajaran dilakuan oleh penyaji I, II, III, IV dengan menerapkan konsep yang ada kedalam contoh-contoh dan siswa diajak aktif untuk memberikan contoh-contoh penerapan dari teorema yang ada. Pelaksasanaan kegiatan pembinaan kesadaran belajar matematika siswa melalui pendekatan historis berjalan dengan baik. Hal tersebut dapat diamati dari siswa aktif mengikuti kegiatan yang dilakukan dan siswa antusias dalam menyelesaikan soal dalam bentuk permasalahan yang dimunculkan penyaji dan juga aktif bertanya kepada penyaji terhdap materi yang kurang dipahami.
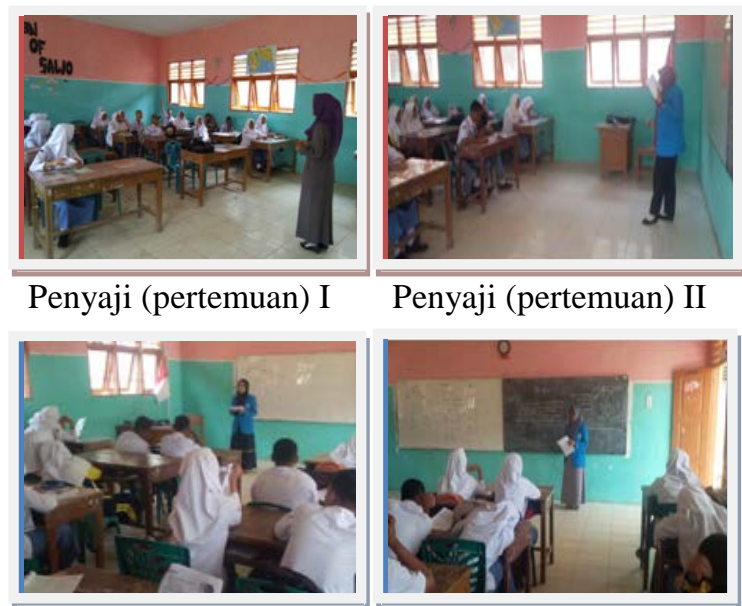

Penyaji (pertemuan) II

Penyaji (pertemuan) III Penyaji (pertemuan) IV

Gambar 4. Pelaksanakan tindakan oleh penyaji

\section{Observasi dan evaluasi}

Observasi dalam kegiatan merupakan pengamatan terhadap aktivitas siswa dalam pemberian pembelajaran matematika dengan pendekatan sejarah dan pemberian angket kesadaran belajar. Sebagai responden yang terlibat adalah satu kelas siswa kelas X MIA 2 SMA Negeri 6 Padangsidimpuan dengan jumlah siswa sebanyak 32 orang. Observasi dilakan oleh tim pengabdi secara langsung dan analisis dokumentasi dalam kegiatan penyajian materi yang dilakukan. Melalui observasi yang dilakukan diperoleh informasi bahwa mengajarkan materi matematika melalui pendekatan sejarah sangat menarik perhatian dari peserta didik, siswa antusias dalam kegiatan pembelajaran yang dilakukan, dan siswa kelihatan mudah memahami materi yang disampaikan ditandai dengan siswa mampu menerapkan teorema yang diberikan kedalam contoh-contoh matematika yang berkaitan dengan kehidupan sehari-hari.

Evaluasi dalam kegiatan ini meliputi pemberian angket yang meliputi angket awal (pretes) dan angket akhir (postes) tentang kesadaran belajar matematika. Angket kesadaran belajar ditinjau dari empat aspek yang meliputi prilaku, kebiasaan, gaya dan kepribadian dalam belajar matematika. Evaluasi yang dilakukan disertai dengan pemberian pertanyaan sebagai pembanding terhadap hasil tanggapan pernyataan dari angket yang diperoleh. Berdasarkan angket yang diberikan diperoleh informasi bahwa:

Tabel 2. Perolehan Nilai Angket Kesadaran Belajar Matematika Siswa

\begin{tabular}{|ccccc|}
\hline Kategori & \multicolumn{2}{c}{ Pretes } & \multicolumn{2}{c|}{ Postes } \\
\cline { 2 - 5 } & Jumlah Persentase & Jumlah & Persentase \\
\hline $\begin{array}{c}\text { Sangat } \\
\text { Tinggi }\end{array}$ & 0 & 0,00 & 6 & 18,75 \\
\hline Tinggi & 14 & 43,75 & 16 & 50,00 \\
\hline Sedang & 11 & 34,38 & 10 & 31,25 \\
\hline Rendah & 7 & 21,88 & 0 & 0,00 \\
\hline $\begin{array}{c}\text { Sangat } \\
\text { Rendah }\end{array}$ & 0 & 0,00 & 0 & 0,00 \\
\hline
\end{tabular}

Berdasarkan tabel 2. dapat diamati bahwa berdasarkan angket kesadaran belajar matematika bahwa melalui pretes 
belum terdapat siswa yang mampu mencapai sangat tinggi dan pada postes terdapat 6 orang $(18,75 \%)$ yang berada pada kategori sangat tinggi. Selanjutnya terdapat 14 orang $(43,75 \%)$ yang berada pada kategori tinggi pada pretes dan 16 orang (50\%) yang berada pada kategori tinggi pada postes. Selanjutnya pada kategori sedang terdapat 11 orang $(34,38 \%)$ melalui pretes dan 10 orang (31,25\%) melalui postes. Sedangkan pada kategori rendah terdapat 7 orang $(21,88 \%)$ melalui pretes dan tidak terdapat siswa kategori rendah dalam postes, begitu juga halnya pada kategori sangat rendah tidak ditemukan siswa melalui pretes dan postes.

\section{Berdasarkan}

kriteria

pengkategorian rata-rata secara umum dari 4 indikator kesadaran matematika yang meliputi melalui pretes diperoleh nilai rata rata siswa adalah sebesar 74 (kategori sedang) selanjutnya pada postes nilai rata rata perolehan siswa adalah 79 (kategori tinggi). Berdasarkan perubahan nilai ratarata perolehan nilai siswa maka melalui penerapan kegiatan yang dilakukan terjadi perubahan perolehan nilai rata rata siswa menjadi lebih baik. Berdasarkan uraian tentang perolehan nilai angket kesadaran belajar matematika siswa yang diuraikan sebelumnya dapat dicermati pada diagram batang berikut.

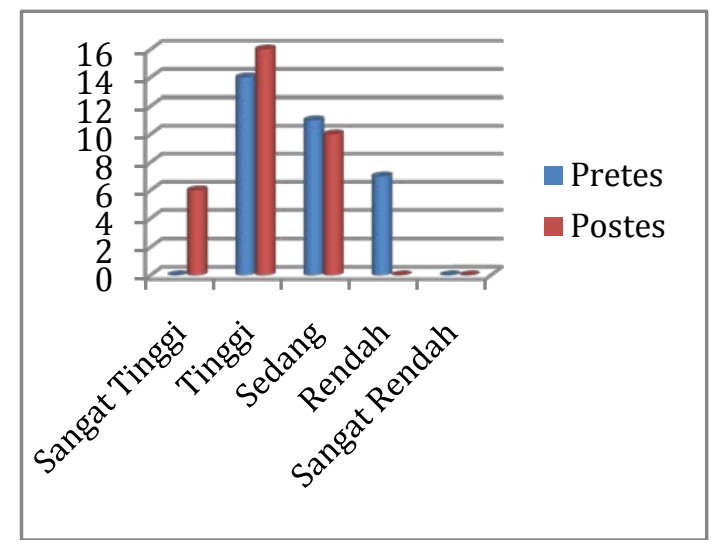

Gambar 3. Capaian Angket Kesadaran Siswa

Selanjutnya dari pertanyaan yang diberikan diperoleh informasi bahwa dengan pembelajaran matematika dengan pendekatan historis siswa tertarik, suka dan menyenangkan dalam kegiatan pembelajaran yang dilakukan dan memberikan tanggapan antara lain: merasa lebih menambah wawasan nya dalam ilmu matematika, menghindari kebosanan dalam belajar matematika, siswa merasa lebih paham terhdap materi pelajaran. Beberapa tanggapan siswa melalui jawaban tertulis tentang kegiatan $\mathrm{PkM}$ meningkatkan kesadaran berlajar matematika siswa melalui pendekatan historis antara lain.

Gaya sangat tartarik apabila parazaran matamalika disanai dongan Cajarah? Iahimyza IImu matomiatlika

\begin{tabular}{lrr}
\multicolumn{2}{c}{ Jawaban tersebut merupakan } \\
tanggapan siswa (s-12) terhadap
\end{tabular}
ketertarikan siswa mengikuti pembelajaran dengan pendekatan historis. Dari jawaban yang diberikan dapat di pahami bahwa siswa sangat tertarik apabila pembelajaran matematika yang dilakukan senantiasa diawali dengan membahas sejarah ahli-ahli matematika sebelum memulai kegiatan pembelajaran. Jawaban lain dari siswa dapat dilihat pada gambar berikut.

Ya, karena balan hanna mumpelujari matematika sanjat boson oloh kareno ith sayja sangat setugu matemativa di seyjal deh sejarah sejarah illmumya

Jawaban dari siswa tersebut mengungkapkan bahwa jika pembelajaran matematika langsung kepada pembahasan materi maka pelajaran itu sangat membosankan dan kurang menarik perhatian, selanjutnya siswa tersebut sangat setuju apabila pengajaran matematika pemyampaiannya disertai dengan sejarah lahirnya tokoh dan ilmu matematika. Siswa lainnya juga memberikan tanggapan.

Setuju dengan pengajaran matematika dengan pendekatan historis dimana siswa lebih tertarik dalam kegiatan pembelajarannya dan lebih memahami 
konsep dan teori matematika yang sedang dipelajari.

\section{Refleksi}

Berdasarkan perolehan nilai rata rata siswa pada postes lebih baik daripada pretes atau peningkatan dari nilai 73,79 menjadi 79,41 maka dapat dipahami bahwa terdapat pengaruh positif dari kegiatan pembelajaran matematika melalui pendekatan historis. Dari aspek kualitas maka secara umum tingkat kesadaran siswa berubah dari kualitas sedang menjadi tinggi. Memperhatikan jawaban siswa melalui soal tanya jawab tulis yang diberikan setelah pelaksanaan kegiatan secara umum siswa berminat dalam pembelajaran matematika. Pertanyaan tentang keterpahaman siswa tentang sejarah matematika sebagian besar siswa memberi jawaban mulai memahami tentang sejarah lahirnya ilmu matematika dan tentang tokoh matematika. Tokoh sejarawan yang diketahui siswa, melalui pertanyaan yang diajukan secara umum siswa menjawab dengan nama tokoh yaitu Al-Battani, John Venn, Pythagoras, Aljabar dan Thales. Terkait pertanyaan pada ketertarikan siswa untuk pembelajaran selanjutnya dengan pendekatan historis keseluruhan siswa sangat tertarik/sangat setuju dengan alasan yang dominan siswa yaitu agar belajar matematika tidak terlalu membosankan dan menambah wawasan tentang sejarah munculnya ilmu matematika dan bisa lebih memahami pelajaran matematika.

\section{SIMPULAN DAN SARAN}

Untuk dapat meningkatkan kesadaran belajar matematika siswa perlu dilakukan pendekatan historis. Dimana melalui pendekatan historis dalam membina kesadaran belajar matematika siswa kelas $\mathrm{X}$ MIA 2 SMA Negeri 6 Padangsidimpuan dengan jumlah siswa sebanyak 32 orang yang ditinjau dari aspek prilaku, kebiasaan, gaya belajar dan kepribadian belajar siswa dapat meningkat. Peningkatan ini dapat dilihat dari nilai rata rata hasil awal angket kesadaran belajar siswa $(73,79)$ berada dalam kategori sedang dan nilai rata rata akhir angket kesadaran siswa $(79,41)$ berada dalam kategori baik. Selain itu Kegiatan pengabdian dalam pengajaran matematika dengan pendekatan historis dirasakan banyak memberi pemahaman dan manfaat bagi siswa yang mengikuti kegiatan karena mereka belum pernah mengikuti kegiatan serupa. Kegiatan dilaksanakan dengan pendekatan historis melalui tokoh-tokoh sejarawan matematika yang berdampak siswa merasa lebih berminat, lebih memahami materi pelajaran dan siswa lebih senang dalam kegiatan pembelajaran matematika yang dilakukan.

Berdasarkan kegiatan pembahasan hasil kegiatan PkM yang dilakukan, penulis menyampaikan saran sebagai berikut: 1) Untuk meningkatkan kesadaran belajar matematika, guru (pendidik) diharapkan mengulas sejarah penemuan dari materi matematika untuk mengawali pembelajaran agar siswa lebih tertarik dan lebih berminat dalam mengikuti pembelajaran; 2) Bagi siswa peserta didik pembelajaran matematika diharapkan agar lebih banyak memahami sejarah matematika dan lebih sering menceritakan sejarah tersebut agar dirinya sendiri lebih tertarik dengan matematika begitu juga dengan teman yang mendengarkan cerita tersebut.

\section{UCAPAN TERIMA KASIH}

Peneliti mengucapkan terima kasih kepada Institut Pendidikan Tapanuli Selatan yang telah memberikan pendaanaan dalam kegiatan Pengabdian kepada Masayarakat (PkM) Dosen Internal Tahun Pelaksanaan 2019. Selanjutnya penulis juga mengucapkan terimakasih kepada pimpinan dan pengurus SMA Negeri 6 Padangsidimpuan yang telah mendukung jalannya pelaksanaan kegiatan PkM kepada tim pengabdi dalam melaksanakan kegiatan di sekolah tersebut pada tahun 2019. 
Marzuki Ahmad, dkk. Pembinaan Kesadaran Belajar Matematika....

DAFTAR PUSTAKA

Abusiri. (2017). Media Pembelajaran dan Upaya Membangun Kesadaran Belajar Siswa. HIKMAH, XIII(1), 3664. Retrieved from http://journal.alhikmahjkt.ac.id/index. php/HIKMAH/article/view/81/62

Ahmad, M., \& Nasution, D. P. (2018). Analisis Kualitatif Kemampuan Komunikasi Matematis Siswa Yang Diberi Pembelajaran Matematika Realistik. Jurnal Gantang, III(2), 8395. https://doi.org/10.31629/jg.v3i2.471

Fahmi, R. (2015). Membangun Kesadaran Belajar. Retrieved from https://www.kompasiana.com/www.k ompasiana_robith.com

Fathurrohman, M. N. (2014). Tokoh Ilmuwan Penemu bidang Matematika. Retrieved from https://blogpenemu.blogspot.com/201 4/08/tokoh-ilmuwan-penemu-bidangmatematika.html

Fitriani, Novitasari, W., \& Siregar, Y. A. (2018). Workshop Pengembangan Bahan Ajar. MARTABE: Jurnal Pengabdian Masyarakat, 1(3), 149157.

https://doi.org/10.31604/jpm.v1i3.149 $-157$

Harahap, A. F. D., Tuah, S., Ariaji, R., \& Mulyana, V. (2017). Pelatihan dan Pendampingan Pengembangan Media Pembelajaran Menggunakan Microsoft Power Point dan Camtasia di Smamuhammadiyah 11 Kota Padangsidimpuan. MARTABE : Jurnal Pengabdian Masyarakat, 1(1), 7-11. https://doi.org/10.31604/jpm.v1i1.711

Ilyas, S. (2016). Membangun Kesadaran Belajar Siswa. Retrieved from https://belitongekspres.co.id/memban gun-kesadaran-belajar-siswa

Istiyani, D. (2009). Kesadaran dan Self Directed Learning sebagai Model Pembelajaran Alternatif dalam Era Neoliberalisme. FORUM TARBIYAH, 7(2), 131-142. Retrieved from https://media.neliti.com/media/public ations/89818-ID-kesadaran-dan-selfdirected-learning-seb.pdf\%0A

Lubis, F. A., Dongoran, P., \& Lubis, J. A. (2018). “Pengeminitor” Pelatihan Penyusunan Instrument Penilaian Kognitif dan Psikomotorik pada Guru- Guru Muhammadiyah Kota Padangsidimpuan. MARTABE: Jurnal Pengabdian Masyarakat, 1(3), 158-164. https://doi.org/10.31604/jpm.v1i3.158 $-164$

Nurulia, L. (2016). Konsep Kesadaran Diri dan Kemauan Belajar Mandiri Sebagai Dasar Model Pembelajaran Inquiry di Era Pendidikan Modern. Retrieved from https://bdksemarang.kemenag.go.id/k onsep-kesadaran-diri-dan-kemauanbelajar-mandiri-sebagai-dasar-modelpembelajaran-inquiry-di-erapendidikan-modern/

Rama. (2016). Daftar Tokoh Penemu Bidang Matematika. Retrieved from https://kumpulanpenemudunia.blogsp ot.com/2016/01/daftar-tokohpenemu-bidang-matematika.html

Sukoyo, M. U. (2014). Pengaruh Kesadaran Belajar, Kemandirian Belajar, dan Fasilitas Bengkel terhadap Kompetensi Siswa pada Mata Diklat Dasar Instalasilistrik di SMK N 3 Yogyakarta. Universitas Negeri Yogyakarta. Retrieved from http://eprints.uny.ac.id/30056/1/M. Umam Sukoyo 10501249001.pdf 